\title{
LUTEAL FUNCTION IN HYSTERECTOMIZED GOATS
}

\author{
W. B. GURRIE* AND G. D. THORBURN $\dagger$ \\ C.S.I.R.O., Division of Animal Physiology, Ian Clunies Ross Animal Research Laboratory, \\ P.O. Box 239, Blacktown, N.S.W. 2148, Australia
}

(Received 20th Fune 1974)

There is an obligatory requirement for continued secretory activity of the goat CL throughout pregnancy because the placenta does not secrete progesterone in this species (Linzell \& Heap, 1968; van Rensburg, 1971; Thorburn \& Schneider, 1972; Irving, Jones \& Knifton, 1972a). Ovariectomy or ablation of the CL during pregnancy inevitably causes abortion, the effects being due solely to the withdrawal of progesterone (Meites, Webster, Young, Thorp \& Hatch, 1951; Irving et al., 1972a). Regression of the CL, as indicated by an abrupt decline in circulating progesterone concentrations, occurs on the day before parturition at term (gestation length $150 \pm 3$ days) and also before pathological abortion (van Rensburg, 1971). Van Rensburg (1971) has suggested that the decrease in progesterone may reflect a withdrawal of maternal pituitary luteotrophin as a result of hypothalamic 'timing'. The recent demonstration, however, that parturition can be induced prematurely in goats by causing precocious secretory activity of the fetal adrenal cortex (Thorburn, Nicol, Bassett, Shutt \& Cox, 1972) indicates that the fetus may play an active rôle in controlling luteolysis and therefore the functional lifespan of the CL.

As part of a study examining endocrine factors controlling the onset of parturition in the goat, this paper defines the secretory lifespan of CL in hysterectomized goats and compares their functional activity with that already described during pregnancy (Thorburn \& Schneider, 1972; Irving et al., 1972b).

Three Saanen and three feral goats were anaesthetized using halothane (Fluothane, I.C.I.) inhalation 30 to 49 days after fertile mating (see Table 1) and were hysterectomized through a mid-line incision. Precautions taken to minimize the release of endogenous luteolysin during surgery included premedication with $15 \mathrm{mg}$ progesterone injected intramuscularly in oil 3 to $5 \mathrm{hr}$ before surgery and rapid ligation of the uterine veins before radical dissection of the uterus and ligaments. The cervix was sectioned between heavy anchored ligatures and the mesovarium was dissected to leave the ovaries containing CL on vascular pedicles. Jugular venous blood was collected by venepuncture before injecting the progesterone, at daily intervals for 7 days after surgery, every 2 to 5 days for a further 70 days, and daily thereafter. Plasma was separated, stored at $-20^{\circ} \mathrm{C}$ and assayed for progesterone as described by Thorburn \& Schneider (1972) with the exception that all data presented here

\footnotetext{
* Present address: Protein and Polypeptide Hormone Laboratory, Department of Physiology, University of Manitoba, 770 Bannatyne Avenue, Winnipeg, Manitoba R3E OW3, Canada.

$\dagger$ Present address: Nuffield Department of Obstetrics and Gynaecology, John Radcliffe Hospital, Headington, Oxford OX3 9DU.
} 
Table 1. Description of animals and secretory lifespan of corpora lutea in hysterectomized goats

\begin{tabular}{|c|c|c|c|c|}
\hline Goat no. & $\begin{array}{l}\text { Time of hysterectomy } \\
\text { after mating (days) }\end{array}$ & No. of $C L$ & $\begin{array}{c}\text { Preoperative progesterone } \\
\text { concentration }(\mathrm{ng} / \mathrm{ml})\end{array}$ & $\begin{array}{l}\text { Days from mating until } \\
\text { regression of } C L^{*}\end{array}$ \\
\hline $\begin{array}{l}259 \\
294 \\
295 \\
314 \\
336 \\
338\end{array}$ & $\begin{array}{c}46 \\
46 \\
49 \\
47 \\
30(-5) \dagger \\
48\end{array}$ & $\begin{array}{l}1 \\
1 \\
1 \\
2 \\
1 \neq \\
2\end{array}$ & $\begin{array}{l}7 \cdot 0 \\
4 \cdot 3 \\
7 \cdot 2 \\
7 \cdot 7 \\
0 \cdot 9 \\
6 \cdot 5\end{array}$ & $\begin{array}{l}161 \\
159 \\
184 \\
147 \\
148 \dagger \\
151\end{array}$ \\
\hline
\end{tabular}

* Regression timed as the first of at least 3 consecutive days with plasma progesterone levels $<0.5$ $\mathrm{ng} / \mathrm{ml}$.

$\dagger$ Time of ovulation assessed from progesterone data in Text-fig. 1 to be 5 days after surgery.

$\ddagger$ Number of CL not known; ovulation occurred after surgery.

have been corrected for procedural losses during assay. The latter were determined by measuring the recovery of 2,4 and $8 \mathrm{ng}$ progesterone $/ \mathrm{ml}$ added to the plasma of an anoestrous goat; the mean recovery was $84.9 \pm 2.7 \%$ (mean \pm S.E.M., $n=24$ ).

At surgery, one animal (No. 336, 30 days after mating) contained a dead embryo with autolysed membranes, and the CL, pale yellow in colour and lacking the usual superficial blood vessels, was evidently regressing. The five other goats had normal CL and each had one or two live fetuses with membranes of normal appearance. Jugular progesterone concentrations (Text-fig. 1) in the five animals with normal fetuses were similar. The low levels in Goat 336 at surgery and the subsequent marked elevation indicated that ovulation occurred on the 5th day after operation (see Text-fig. 1). Progesterone concentrations in the other five goats generally decreased over a period of 5 to 10 days, remained relatively constant for a variable length of time, and then decreased either gradually or abruptly to anoestrous levels $(<0.5 \mathrm{ng} / \mathrm{ml})$. The final decline to $<0.5 \mathrm{ng} / \mathrm{ml}$ was chosen, a priori, as an index of functional regression and these concentrations were reached 147 to 184 days after mating. The pattern of change in progesterone concentrations in Goat 314 was such that a precise timing of functional regression was equivocal. Progesterone concentrations remained fairly stable at $4 \mathrm{ng} / \mathrm{ml}$ from 12 days after hysterectomy until 132 days after mating, then decreased fairly abruptly to $1.4 \mathrm{ng} / \mathrm{ml}$ by Day 134 and finally reached $<0.5 \mathrm{ng} / \mathrm{ml}$ by Day 147 . In Goat 336 , in which ovulation probably occurred by Day 0 as indicated in Text-Fig. 1, progesterone concentrations were maximal by Day 9 , progressively declined over the next 100 days and finally decreased to $<0.5 \mathrm{ng} / \mathrm{ml}$ by Day 148 .

Plasma concentrations of progesterone decreased after hysterectomy and, throughout the lifespan of the CL, remained at levels less than half those measured in intact pregnant goats (Thorburn \& Schneider, 1972; Irving et al., 1972b). The depression in luteal function after hysterectomy suggests that the maintenance of full functional activity of CL in goats during pregnancy may be dependent on the presence of a placental luteotrophin. Buttle, Forsyth \& Knaggs (1972) have identified a lactogen of placental origin in goat plasma during the last 90 days of pregnancy. 
The present data indicate that maintenance of progesterone secretion occurs in hysterectomized goats, albeit at a depressed level, for a variable length of time after mating (147 to 184 days). In three of the six goats, the time exceeded the normal luteal lifespan in intact pregnant animals, suggesting that cessation of progesterone production, which precedes parturition in this species, is unlikely to be determined solely by a maternal hypothalamic factor, as has been suggested by van Rensburg (1971). A more likely explanation can be proposed from the results of studies (Thorburn et al., 1972; Bassett \& Thorburn, 1973; Currie, Wong, Cox \& Thorburn, 1973) in which luteolysis was shown to occur

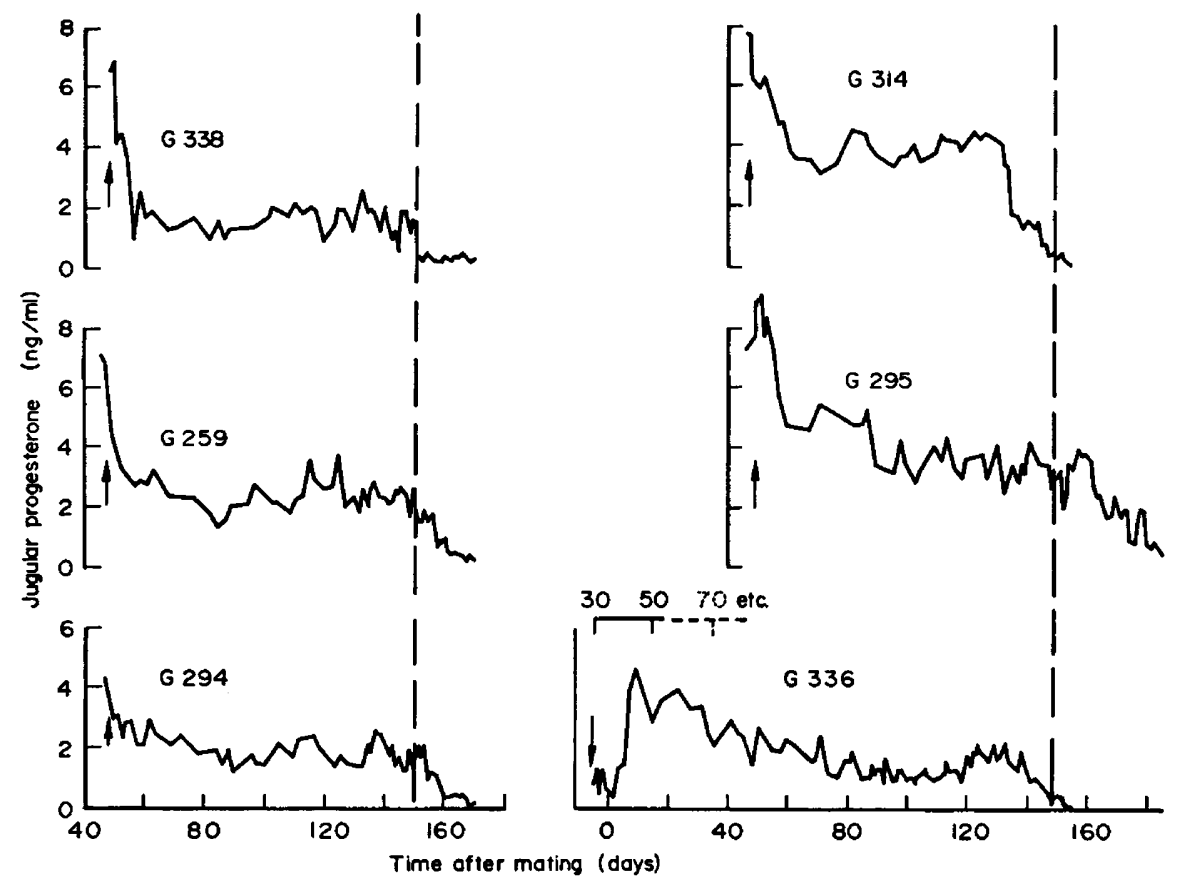

TEXT-rig. 1. Changes in jugular plasma progesterone concentrations in six hysterectomized goats in relation to the time after mating (the actual time after mating for Goat 336 is shown above the data; the scale below corresponds to the probable time of ovulation after surgery as discussed in the text). Arrows signify the day of surgery, and vertical broken lines at 149 days indicate the mean time of luteal regression in intact pregnant goats.

during times of heightened adrenocortical activity in the goat fetus. The time of luteolysis corresponds closely to the appearance of prostaglandins of the $F$ group in utero-ovarian venous blood of goats (Currie et al., 1973; Currie, 1974) and equivalent amounts of exogenous prostaglandin $\mathrm{F}_{2 \alpha}$ are luteolytic in pregnant goats (Currie \& Thorburn, 1973). The timing of luteolysis before parturition in goats may, therefore, involve prostaglandin $\mathrm{F}$ secretion controlled by elevated corticosteroids in the fetus.

One of us (W.B.C.) was a recipient of a C.S.I.R.O. Postgraduate Studentship held in the School of Biological Sciences, Macquarie University. 


\section{REFERENGES}

Bassett, J. M. \& Thorburn, G. D. (1973) Circulating levels of progesterone and corticosteroids in the pregnant ewe and its foetus. In Endocrinology of Pregnancy and Parturition. Studies in the Sheep, p. 126. Ed. G. G. Pierrepoint. Alpha Omega Alpha Publishing, Cardiff.

Buttle, H. L., Forsyth, I. A. \& Knaggs, G. S. (1972) Plasma prolactin determined by radioimmunoassay and bioassay in pregnant and lactating goats and the occurrence of a placental lactogen. 7. Endocr. 53, 483.

CURRIE, W. B. (1974) Regression of the corpus luteum of pregnancy and initiation of labour in goats. F. Reprod. Fert. 36, 481.

GURRIE, W. B. \& ThORBURN, G. D. (1973) Induction of premature parturition in goats by prostaglandin $F_{2 a}$ administered into the uterine vein. Prostaglandins, 4, 201.

Gurrie, W. B., Wong, M. S. F., Cox, R. I. \& Thorburn, G. D. (1973) Spontaneous or dexamethasone induced parturition in the sheep and goat: changes in maternal prostaglandin $F$ and foetal oestrogen sulphate concentrations. Mem. Soc. Endocr. 20, 95.

Irving, G., Jones, D. E. \& Knifton, A. (1972a) Progesterone concentrations in the peripheral plasma of pregnant goats after ovariectomy and replacement therapy. Res. vet. Sci. 13, 301 .

Irving, G., Jones, D. E. \& Knifton, A. (1972b) Progesterone concentration in the peripheral plasma of pregnant goats. J. Endocr. 53, 447.

LinzelL, J. L. \& HEAP, R. B. (1968) A comparison of progesterone metabolism in the pregnant sheep and goat: sources of production and an estimation of uptake by some target organs. F. Endocr. 41, 433.

Meites, J., Webster, H. D., Young, F. W., Thorp, F. \& Hatch, R. N. (1951) Effects of corpora lutea removal and replacement with progesterone on pregnancy in goats. J. Anim. Sci. 10, 144.

Thorburn, G. D., Nicol, D. H., Bassett, J. M., Shutt, D. A. \& Cox, R. I. (1972) Parturition in the goat and sheep: changes in corticosteroids, progesterone, oestrogens and prostaglandin $F$. J. Reprod. Fert., Suppl. 16, 61.

Thorburn, G. D. \& Schneider, W. (1972) The progesterone concentration in the plasma of the goat during the oestrous cycle and pregnancy. F. Endocr. 52, 23.

van RensBurg, S. J. (1971) Reproductive physiology and endocrinology of normal and habitually aborting angora goats. Onderstepoort $\mathcal{J}$. vet. Res. 38, 1. 